\title{
A comparison of the actions of different bronchodilators in asthma
}

\author{
BERNARDJ.FREEDMAN ${ }^{1}$, PETER MEISNER ${ }^{2}$, AND \\ G. B. $\mathrm{HILL}^{3}$ \\ From Dulwich Hospital, King's College Hospital Group, London, S.E.22, ${ }^{1}$ and \\ the General Register Office, Somerset House, London, W.C. $2^{s}$
}

The actions of the following pressurized bronchodilators were compared by administration to 24 asthmatics: (1) Medihaler Iso Forte, (2) Alupent, (3) Medihaler-duo, (4) Bronchilator, and (5) Prenomiser Plus. These contained one or more of the following: isoprenaline, orciprenaline, isoetharine, phenylephrine, atropine methonitrate, and thenyldiamine. The dose was a single discharge from the container. The response was assessed by calculating the mean percentage change in F.E.V. at intervals after inhalation.

The mean peak rises were respectively (1) $49.4 \%$, (2) $43.6 \%$, (3) $36.2 \%$, (4) $33.5 \%$, and (5) $23.5 \%$. The amplitude of peak response to isoprenaline was related to the logarithm of the dose. Weight for weight, orciprenaline had a peak bronchodilator activity $41.5 \%$ that of isoprenaline and isoetharine $50 \%$. The preparations did not differ significantly in the time taken to reach maximum response, which varied from 5 to 60 minutes; three-quarters of the maxima occurred within 15 minutes.

The half-life for Alupent was 2 hours ; for Medihaler-duo, which contains $240 \mu \mathrm{g}$. of phenylephrine per dose, it was $1 \frac{1}{4}$ hours ; for the remaining preparations it was about 1 hour. The decay rate, after the first half-hour, was $6 \%$ of the basal F.E.V. per hour for Medihaler-duo; for the other preparations it was, $10-12 \%$. In the doses given, Alupent yielded $20 \%$ and $30 \%$ increases lasting 130 and 67 minutes; after Medihaler Iso Forte these lasted 78 and 46 minutes. Similar comparative experiments, designed to eliminate effects of dosage difference, are desirable. Rebound bronchoconstriction occurred in $23 \%$ of 92 experiments. There was no response to propellent alone. The mean percentage change in F.E.V. may not be the best way of expressing results.

No fewer than 28 varieties of bronchodilator aerosol are available commercially in Britain today. Eight of these are supplied in solution, and 20 in pressurized containers. Almost all of them differ in composition and dosage. The confusion of choice presented by this wide range is scarcely resolved by the published results of numerous drug trials in which two or more bronchodilators have been compared.

Some comparative trials that have been published may be quoted:

Isoprenaline and orciprenaline (Woolcock, Tai, and Pain, 1964 ; Edwards, 1964 ; Illig, 1965 ; Fischer and Mielke, 1965).

Isoprenaline and atropine (Chamberlain, Muir, and Kennedy, 1962; Kennedy and ThursbyPelham, 1964 ; Capel and Fletcher, 1964).

\footnotetext{
2 Present address : Lewisham Hospital, London, S.E.13
}

Isoprenaline and Bronchilator (Jacobsen and Prime, 1965 ; El-Shaboury, 1964 ; Pickworth and Westwood, 1965).

Isoprenaline and isoprenaline with phenylephrine (Cohen and Hale, 1965 ; Kallós and KallósDeffner, 1964).

Isoprenaline and isoprenaline with deptropine (Kennedy, 1965 ; Prime, 1968).

Isoprenaline, orciprenaline, and isoprenaline with atropine (Sinclair, 1966).

Isoprenaline, orciprenaline, and Bronchilator (Hoffbrand, Hoffbrand, Hill, and Heaf, 1966). Isoprenaline, isoprenaline with atropine, isoprenaline with phenylephrine, orciprenaline, and Bronchilator (Mattila and Muittari, 1966).

Without exception each trial has differed from others in some respect, such as selection of patientgroups, dosage of drug, mode of administration, and method of expressing the amplitude and 
duration of response. Consequently, the various results are not strictly comparable and no very clear picture emerges regarding the relative merits of the various drugs and their marketed preparations.

In an attempt to resolve the confusion of choice arising from this situation, we selected five pressurized aerosols for comparative trial. The preparations were Medihaler Iso Forte, Medihalerduo, Bronchilator, Prenomiser Plus, and Alupent. Table I shows their composition and the dose of each component drug in micrograms delivered by a single discharge from the container as stated by the manufacturers. ${ }^{1}$ They were tested with the following criteria in view:

1. Potency of bronchodilator activity, i.e., amplitude of maximum response

2. Time taken to reach maximum response

3. Extent to which differences in bronchodilator activity can be ascribed to differences in dosage

4. Duration of effect

5. Influence of adjuvant substances

6. Incidence of rebound bronchoconstriction

7. Absence of response to propellent.

The introduction of isoprenaline marked an important advance on adrenaline, since it acts exclusively on $\beta$-receptors. However, it increases the force and frequency of the heart-beat and dilates blood-vessels in skeletal muscle, and hence may cause palpitations, headache, and hypotension. More recently, the occurrence of occasional dangerous cardiovascular effects has been suspected (Lockett, 1965 ; Greenberg and Pines, 1967, and subsequent correspondence ; Speizer, Doll, Heaf, and Strang, 1968).

Isoetharine was found by animal experiment to protect guinea-pigs from histamine-induced bronchospasm (Siegmund, Granger, and Lands, 1947). Its cardiovascular effects were found to be smaller than those of isoprenaline (Lands, Luduena, Grant, and Ananenko, 1950). It was introduced ino clinical practice by Hersohfus, Bresnick, Levinson, and Segal (1951), who on a weight-for-weight basis found it to have approximately one-third of the bronchodilator effect of isoprenaline.

Orciprenaline was also found by animal experiment to exert a smaller cardiovascular effect and

\footnotetext{
1 The dose is estimated by the manufacturer in the following way. The concentration of drug in the suspension is assayed chemically. A batch of valves is sampled statistically, and the volume of the valve-chamber checked. The proportion of the discharged dose which is retained by the apparatus is measured. The dose delivered is the amount discharged less the amount retained in the apparatus
}

a more persistent bronchodilator effect than isoprenaline (Engelhardt, Hoefke, and Wick, 1961), and it was introduced into clinical practice by Spitzbarth and Albers (1961).

Phenylephrine, present in Medihaler-duo and in Bronchilator, is a sympathomimetic amine acting on $\alpha$-receptors. Its function is to cause vasoconstriction in the bronchial mucosa, delay absorption of the bronchodilator, and so prolong its duration of effect. That such prolongation may occur has been demonstrated by Kallós and Kallós-Deffner (1964) in histamine-induced bronchospasm, and by Cohen and Hale (1965) in chronic bronchitis and pulmonary emphysema, though Mattila and Muittari (1966)did not achieve this result. Phenylephrine might also have a slight indirect bronchodilator effect by constricting mucosal blood-vessels whose engorgement contributes to airway narrowing. Goldfarb and Romanoff (1962) obtained evidence of bronchodilator action from phenylephrine alone.

Atropine methonitrate causes bronchodilatation more slowly but more persistently than does isoprenaline. When given together with isoprenaline the actions are additive (Capel and Fletcher, 1964) and the effect is that of prolonging the bronchodilatation initiated by the isoprenaline (Chamberlain et al., 1962). Its mode of action is presumably by the reduction of vagally mediated bronchoconstrictor tone. It reverses bronchoconstriction caused by inhalation of various dusts (Dautrebande, Lovejoy, and McCredie, 1962 ; Widdicombe, Kent, and Nadel, 1962) and by hypoxia (Astin and Penman, 1967).

Thenyldiamine is an antihistamine. Although antihistamines relieve histamine-induced bronchospasm (Altounyan, 1964), their effect in naturally occurring asthma is dubious.

\section{METHOD}

The preparations were given to 24 asthmatic subjects, 18 men and 6 women. The age range was 19 to 70 (mean 43.2) years. The diagnostic criteria were those of Scadding (1963). Excluded from the trial were patients suffering from chronic bronchitis-namely, those producing sputum on most days for at least three months in the year and for at least two years, those prone to recurrent chest infections, and those whose airway obstruction did not vary in severity over short periods of time. Tests were undertaken when the patients were in a steady state of moderate bronchospasm as estimated clinically and by comparison of the forced expiratory volume in one second (F.E.V.) with each patient's expected value. The pretreatment F.E.V. was expressed as a percentage of the expected F.E.V. for each patient. The mean of 
T A B L E I

BRONCHODILATOR AEROSOLS: COMPOSITION AND QUANTITY OF COMPONENTS ( $\mu$ g.) DELIVERED IN ONE DOSE, AND NUMBER OF PATIENTS RECEIVING EACH PREPARATION

\begin{tabular}{|c|c|c|c|c|c|c|c|}
\hline • & $\begin{array}{c}\text { No. } \\
\text { of } \\
\text { Patients }\end{array}$ & $\begin{array}{l}\text { Isoprenaline } \\
\text { Sulphate }\end{array}$ & Isoetharine & Phenylephrine & $\begin{array}{c}\text { Atropine } \\
\text { Methonitrate }\end{array}$ & Orciprenaline & Thenyldiamine \\
\hline Medihaler Iso Forte (Riker) $\ldots$ & 18 & 400 & & & & & \\
\hline Medihaler-duo (Riker) & 19 & 160 & & 240 & & & \\
\hline Bronchilator (Bayer) $\quad$. & 18 & & 320 & 64 & & & 27 \\
\hline Prenomiser Plus (Fisons) & 18 & 100 & & & 40 & & \\
\hline Alupent (Boehringer Ingelheim) & 19 & & & & & 675 & \\
\hline
\end{tabular}

the 24 values was $50.7 \%$. The F.E.V. was measured using a Vitalograph, and the tests were begun at 10 a.m. In order to ensure the absence of residual bronchodilator activity from drugs taken before the tests, patients were forbidden to use bronchodilators during the preceding six hours except in an emergency, in which case the test was postponed. Six patients were on long-term prednisolone administration. The dose of each preparation was a single discharge from the cartridge comprising the components and quantities shown in Table I. Immediately before use the operational efficiency of the cartridge was checked by inspection of the discharge against a dark ground. All patients were well trained in the technique of inhalation, and every act of inhalation was carefully checked as satisfactory by the person carrying out the test.

The response was assessed by preliminary measurement of the F.E.V., which was repeated after inhalation of the aerosol at intervals of $5,15,30,60,90$, 120,150 , and 180 minutes, and thereafter hourly until at least one hour after the F.E.V. had returned to the pre-treatment level (basal). The purpose of continuing so long (sometimes as much as 6 hours) was to detect any rebound bronchoconstriction. The amplitude of response was expressed as percentage change from basal. No patient was given a preparation until several days had elapsed from a previous test with another preparation. Routine inquiry was made regarding subjective side-effects.

It was not possible for all patients to receive all five preparations. The distribution of patients in relation to experiments was as follows:

12 patients received 5 preparations

4 patients received 4 preparations

3 patients received 3 preparations

2 patients received 2 preparations

3 patients received 1 preparation

Each preparation was given to 18 or 19 patients (Table I).

A complete control series using inert inhalant was not examined, as it has previously been established that the five preparations exert bronchodilator activity. A small series of nine patients was given inhalations of propellent alone, and the F.E.V.s were measured over a period of 3 hours, in order to confirm that it was inert.

\section{RESULTS}

AMPLITUDE OF MAXIMUM RESPONSE The maXimum percentage increase in F.E.V. above basal level was taken as a measure of a patient's response to a particular aerosol. Because not all patients received all five aerosols, it was not possible to use simple averages. A more sophisticated method of analysis is required which separates the effects of different aerosols from the responses of individual patients (Kendall and Stuart, 1966). This was done by means of a computer programme which estimates these various effects by the method of least squares. The mean maximum percentage increases thus obtained are shown in Table II and Figure 1.

TIME TO REACH MAXIMUM RESPONSE The distribution of the time of maximum increase in F.E.V.

\section{T A B L E I I}

MEAN MAXIMUM PERCENTAGE INCREASES IN F.E.V. AFTER INHALATION OF SINGLE DOSES FROM THE RESPECTIVE PRESSURIZED CONTAINERS.

\begin{tabular}{lll|l}
\hline Medihaler Iso Forte & $\ldots$ & $49 \cdot 4 \%$ \\
Alupent &. & $\ldots$ & $43 \cdot 6 \%$ \\
Medihaler-duo & $\ldots$ & $\ldots$ & $36.2 \%$ \\
Bronchilator & $\ldots$ & $\ldots$ & $33.5 \%$ \\
Prenomiser Plus & $\ldots$ & $\ldots$ & $23.5 \%$ \\
\hline
\end{tabular}

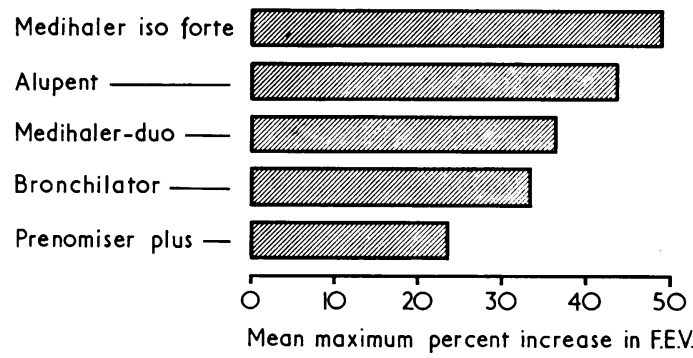

FIG. 1. Mean maximum percent increase in F.E.V. after inhalation of single doses of bronchodilators. 
in the 92 tests is shown in Table III. Peak response occurred at 5 or 15 minutes after aerosol inhalation in $69(75 \%)$ of the 92 tests, and in all but one it occurred within an hour. The differences between the aerosols in this respect is not statistically significant when the results of the 12 patients who received all five preparations are examined by a Friedman two-way analysis of variance by ranks (Friedman, 1937). Mushin (1967) has drawn attention to the need to continue a test for at least half an hour when measuring the maximum response to a bronchodilator. By testing for a longer period we have shown that about one patient in eight achieved a maximum response one hour after inhalation.

T A B L E I I I

NUMBER OF PATIENTS OBTAINING PEAK RESPONSE TO AEROSOLS AT DIFFERENT TIMES AFTER INHALATION

\begin{tabular}{|c|c|c|c|c|c|c|c|}
\hline \multirow{2}{*}{\multicolumn{3}{|c|}{ Aerosol }} & \multicolumn{5}{|c|}{ Minutes after Inhalation } \\
\hline & & & 5 & 15 & 30 & 60 & 90 \\
\hline $\begin{array}{l}\text { Alupent } \quad . \\
\text { Bronchilator .. } \\
\text { Medihaler-duo } \\
\text { Prenomiser Plus } \\
\text { Medihaler Iso Forte }\end{array}$ & $\begin{array}{l}\ldots \\
\cdots \\
\cdots \\
\cdots\end{array}$ & $\begin{array}{l}\cdots \\
\cdots \\
\cdots \\
\cdots\end{array}$ & $\begin{array}{r}4 \\
8 \\
11 \\
8 \\
7\end{array}$ & $\begin{array}{l}9 \\
6 \\
3 \\
5 \\
8\end{array}$ & $\begin{array}{l}3 \\
2 \\
2 \\
3 \\
1\end{array}$ & $\begin{array}{l}3 \\
2 \\
3 \\
1 \\
2\end{array}$ & 1 \\
\hline \multirow[t]{2}{*}{ Total } & \multirow{2}{*}{$\cdots$} & \multirow{2}{*}{$\cdots$} & 38 & 31 & 11 & 11 & 1 \\
\hline & & & \multicolumn{2}{|c|}{$75 \%$} & \multicolumn{3}{|c|}{$25 \%$} \\
\hline
\end{tabular}

DIFFERENCES IN BRONCHODILATOR ACTIVITY DUE TO DIFFERENCES IN DOSAGE If the maximum percentage increase in F.E.V. is regarded as a measure of response in a 'bioassay' of bronchodilator effect, the results demonstrate that differences between the aerosols can be ascribed to dosage. Three of the preparations contain isoprenaline as the bronchodilator.

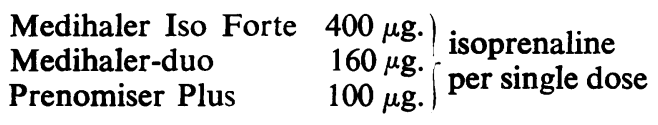

We think we can assume that the adjuvant drugs in these preparations (phenylephrine in Medihaler-duo and atropine in Prenomiser Plus) were exerting negligible bronchodilatation at the early stage (Table III) at which the maximal responses were obtained, and hence that these values were solely the effect of isoprenaline. Figure 2 shows the mean maximum percentage increase in F.E.V. produced by these preparations plotted against the logarithm of the dose of isoprenaline in micrograms (solid circles). The points lie close to a straight line fitted by least squares.

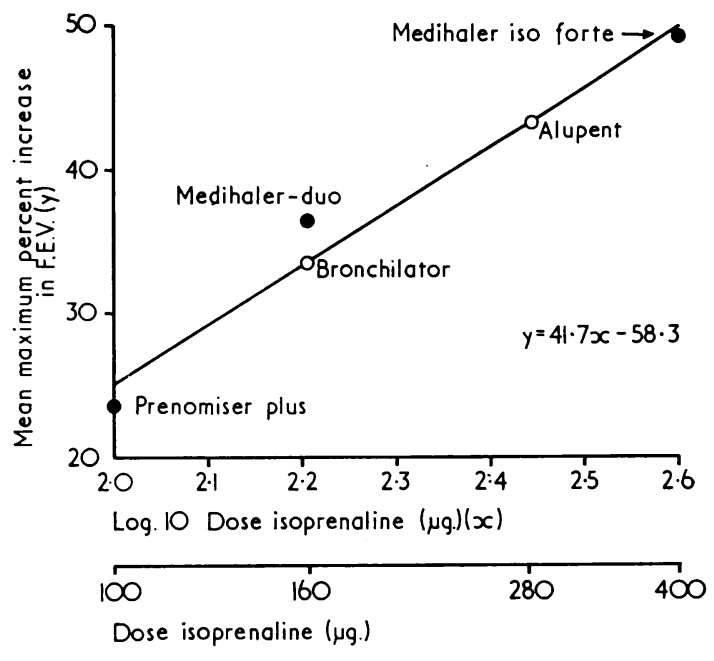

FIG. 2. Bioassay of bronchodilator aerosols. Solid circles represent measured doses and responses. Open circles represent measured responses and hypothetical doses. These have been derived from a line fitted to the solid circles by the method of least squares.

Hence we conclude that, so far as these three preparations are concerned, differences in maximal response are due to differences in dosage.

COMPARATIVE POTENCIES OF ISOETHARINE AND ORCIPRENALINE From the fact that the maximal bronchodilator activity of isoprenaline aerosols is related to the logarithm of the dose, it is possible to express the activity of the other two amines acting on $\beta$-receptors in terms of isoprenaline activity when they are administered by inhalation, again assuming that the adjuvant drugs (phenylephrine and thenyldiamine) exert negligible activity at the early stage of maximal response. The open circles in Fig. 2 show hypothetical positions for Alupent (orciprenaline $675 \mu \mathrm{g}$.) and Bronchilator (isoetharine $320 \mu \mathrm{g}$.) which evoke responses equal to that given by $280 \mu \mathrm{g}$. and 160 $\mu \mathrm{g}$. respectively of isoprenaline.

Weight for weight orciprenaline has $41.5 \%$ the bronchodilator activity of isoprenaline when given by inhalation, and isoetharine has $50 \%$ its activity (Table IV).

DURATION OF EFFECT The percentage changes in F.E.V. that occurred at each time interval after inhalation of the aerosols were averaged, each preparation being treated separately. In all individual tests the F.E.V. increased initially, after which it fell progressively. Occasionally the F.E.V. 
T A B L E I V

BRONCHODILATOR ACTIVITY OF ORCIPRENALINE AND ISOETHARINE EXPRESSED AS PERCENTAGE OF ISOPRENALINE ACTIVITY

\begin{tabular}{|c|c|c|}
\hline & Orciprenaline & Isoetharine \\
\hline \multirow{5}{*}{ 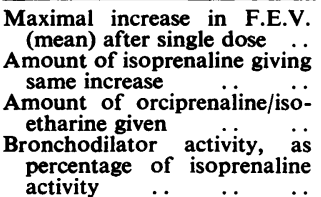 } & $43.6 \%$ & $33.5 \%$ \\
\hline & $280 \mu \mathrm{g}$ & $160 \mu \mathrm{g}$ \\
\hline & & \\
\hline & $675 \mu \mathrm{g}$ & $320 \mu \mathrm{g}$ \\
\hline & $41.5 \%$ & $50 \%$ \\
\hline
\end{tabular}

fell below the basal value and bronchoconstriction was severe enough to curtail the experiment. When this occurred it was assumed, in calculating the averages, that had the experiment continued the F.E.V. would have remained at the same value as was obtained when the experiment was terminated. The same assumption was made if an experiment was concluded at three hours or earlier because the F.E.V. had fallen to, and remained at, the basal level.

The mean percentage changes that occurred during the first three hours after inhalation are shown in Figure 3. During the first 25 minutes the ranking order of the five preparations, in terms of amplitude of response, was the same as that of the maximum response (Table II), and differences between them at this stage are due to the predominating influence of dosage. Thereafter the rates of decline vary. In the doses given,

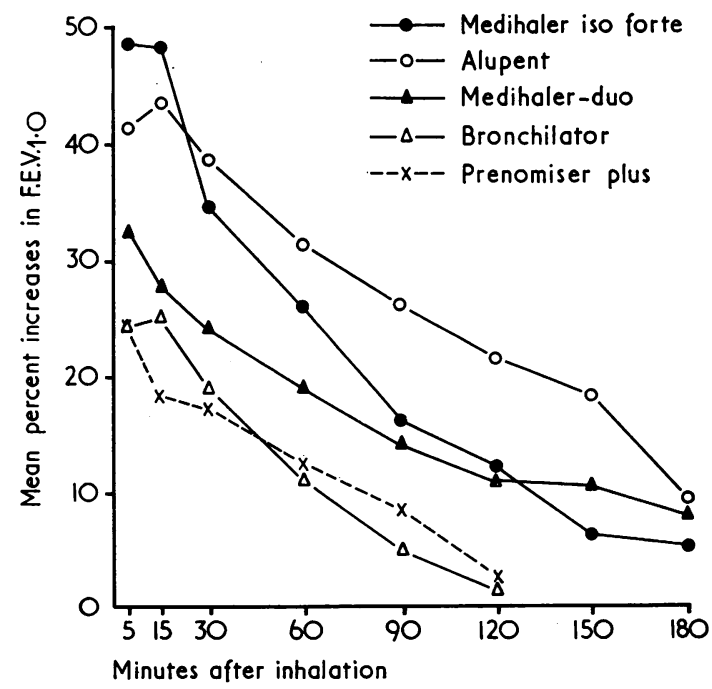

FIG. 3. Mean percent increase in F.E.V. after inhalation of single doses of bronchodilators.
Alupent maintained a greater rise in F.E.V. aftero the first 25 minutes than did the other preparations.

There are several ways of examining and com- $\stackrel{\mathbb{D}}{\Omega}$ paring the durations of effect. The percentage ${ }_{\infty}$ increase in F.E.V. that occurs at any given time $\vec{P}$ after inhalation of a bronchodilator is dependent inter alia on (a) the size of dose, and $(b)$ the $\vec{\omega}$ drug's characteristic rate of rise and fall of activity. Whilst the influence of differences in $\vec{x}$ dosage predominated during the peak period, changes in ranking that occurred subsequently canos be ascribed to a relative increase in the influences of differences in rate of decay of activity of the ${ }^{\circ}$ drugs acting on $\beta$-receptors, as well as to the effect of adjuvant drugs (atropine, phenylephrine, and thenyldiamine).

It is instructive to compare the rates of decline in F.E.V., eliminating as far as possible the influence of differences in dosage.

The times taken for the mean F.E.V. of each $\vec{\bullet}$ preparation to fall to half its maximum value (half-life) are as follows: Alupent $119 \mathrm{~min}$; Medihaler-duo 77 min. ; Medihaler Iso Forte, 650 min.; Prenomiser Plus $64 \mathrm{~min}$.; Bronchilator 545 min. Alupent has the longest half-life (1190 min.). The three isoprenaline preparations have $\frac{}{8}$ similar half-lives, with Medihaler Iso Forte $(65 \circ$ min.) and Prenomiser Plus $(64 \mathrm{~min}$.) havingo virtually identical values, and Medihaler-duo showing a slight advantage, possibly related to its phenylephrine content.

Inferences about F.E.V. values at times other than the half-life are valid only if one assumes ano exponential rate of fall. A linear decay is a reason- $x$ able approximation after the first half-hour. An 3 alternative measure to the half-life is the slope of the regression fitted to the mean percentage improvements from 30 minutes onwards. These slopes, expressed as fall in percent basal F.E.V. per hour, are: Medihaler-duo 6.1 ; Prenomisero Plus 10.0 ; Alupent 10.8 ; Bronchilator 11.9 ; Medihaler Iso Forte $12 \cdot 2$. These calculations in dicate an advantage for Medihaler-duo $(6 \cdot 1 \%$ falin per hour). Prenomiser Plus shows a very small and probably not important advantage over Medihaler Iso Forte $(2 \cdot 2 \%$ per hour), possibly related to its atropine content. The influence of atropine if these experiments has been surprisingly small This may be due to the exclusion of bronchitics:?

The difference in ranking that occurs when one compares half-life with rate of fall per hour isD probably due to the late effects of adjuvants, and notably to phenylephrine, which prolongs the action of isoprenaline in Medihaler-duo. 
A clinical approach to the question of duration of effect involves consideration of what constitutes a useful increase in ventilatory capacity. It is not easy to suggest a percentage rise in F.E.V. that can be accepted for all patients as clinically useful, as there will be individual differences depending on the initial level and on the improvement demanded by the circumstances pertaining at the time. Most physicians will probably agree that an increase in F.E.V. of less than $10 \%$ is valueless, and that patients are more likely to be aware of useful improvement when the F.E.V. has increased by $20 \%$ to $30 \%$. Table $\mathrm{V}$ shows the times after inhalation of single doses of each preparation during which the mean F.E.V. was raised by $20 \%$ and $30 \%$.

\section{T A B L E V}

DURATION (MINUTES) OF MEAN INCREASES IN F.E.V. OF AT LEAST $20 \%$ AND $30 \%$ ABOVE BASAL, OCCURRING AFTER INHALATION OF SINGLE DOSES OF THE PREPARATIONS

\begin{tabular}{|c|c|c|c|c|}
\hline & & & \multicolumn{2}{|c|}{$\begin{array}{c}\text { Increase above } \\
\text { Basal F.E.V. } \\
20 \% \\
30 \%\end{array}$} \\
\hline $\begin{array}{l}\text { Alupent } \\
\text { Medihaler Iso Forte } \\
\text { Medihaler-duo } \\
\text { Bronchilator } \\
\text { Prenomiser Plus }\end{array}$ & $\begin{array}{l}\cdots \\
\cdots \\
\cdots\end{array}$ & $\begin{array}{l}\cdots \\
\cdots \\
\cdots \\
\cdots\end{array}$ & $\begin{array}{r}130 \\
78 \\
54 \\
28 \\
12\end{array}$ & $\begin{array}{l}67 \\
46 \\
10 \\
- \\
\end{array}$ \\
\hline
\end{tabular}

THE EFFECT OF PROPELLENT In order to check that the freon propellent was devoid of activity on the bronchi, nine patients were given inhalations of propellent alone from containers which were indistinguishable from those containing bronchodilator. The changes that occurred during the three hours after inhalation of propellent were small, showing apparently random rises and falls. The mean changes in F.E.V. from basal levels lay between $-3 \cdot 6 \%$ and $+8 \cdot 1 \%$. These were comparable to those obtained by Edwards (1964), El-Shaboury (1964), Jacobsen and Prime (1965), Kennedy (1965), Hoffbrand et al. (1966), and Mattila and Muittari (1966). Of these nine patients, five were taking steroids and four were not. There was no difference between these two groups in the pattern of response to inhalations of propellent.

THE Negative PHASE-REBOUND BRONCHOCONSTRICTION An important aspect of the action of bronchodilators, and one which appears to have received little if any attention in similar trials, is the occasional occurrence, after the F.E.V. has returned to the basal level, of a negative phase during which the F.E.V. is less than its pre-treat- ment value - a state that might be termed 'rebound bronchoconstriction'.

Table VI shows the number of patients whose F.E.V. fell by $15 \%$ or more below basal at various times after inhalation of the five preparations, and the total number affected in this way at any time.

\section{T A B L E V I}

NUMBER OF PATIENTS WHOSE F.E.V. FELL BY $15 \%$ OR MORE AFTER INHALATION OF FIVE BRONCHODILATORS

\begin{tabular}{|c|c|c|c|c|c|c|c|c|c|}
\hline \multirow[t]{2}{*}{ Preparation } & \multirow{2}{*}{$\begin{array}{l}\text { No. of } \\
\text { Patients }\end{array}$} & \multicolumn{7}{|c|}{$\begin{array}{c}\text { Minutes after } \\
\text { Inhalation }\end{array}$} & \multirow{2}{*}{$\begin{array}{c}\text { No. of } \\
\text { Patients at } \\
\text { Any Time }\end{array}$} \\
\hline & & 515 & 30 & 60 & 90 & 120 & 150 & 180 & \\
\hline \multirow{2}{*}{$\begin{array}{l}\text { Bronchilator .. } \\
\text { Alupent } . \\
\text { Medihaler-duo } \\
\text { Mediha'er Iso } \\
\text { Forte } \\
\text { Prenomiser Plus }\end{array}$} & $\begin{array}{l}18 \\
19 \\
19\end{array}$ & 2 & 2 & 2 & $\begin{array}{l}2 \\
1\end{array}$ & $\begin{array}{l}1 \\
2\end{array}$ & $\begin{array}{l}2 \\
2 \\
1\end{array}$ & $\begin{array}{l}2 \\
4 \\
1\end{array}$ & $\begin{array}{l}5 \\
5 \\
4\end{array}$ \\
\hline & $\begin{array}{l}18 \\
18\end{array}$ & & & $\begin{array}{l}1 \\
1\end{array}$ & $\begin{array}{l}1 \\
3\end{array}$ & $\begin{array}{l}\mathbf{1} \\
\mathbf{3}\end{array}$ & $\begin{array}{l}2 \\
2\end{array}$ & $\begin{array}{l}1 \\
2\end{array}$ & $\begin{array}{l}2 \\
5\end{array}$ \\
\hline Total & 92 & 02 & 2 & 4 & 7 & 7 & 9 & 10 & 21 \\
\hline
\end{tabular}

There were no material differences in the time of occurrence of the negative phases: the bulk of the negative phases occurred between 90 and 180 minutes. A few occurred after that time, up to five hours, but the numbers were few and some patients who suffered rebound bronchoconstriction withdrew at an earlier stage. Hence, there are no useful data about the incidence at a very late stage. Only two patients had negative phases after Medihaler Iso Forte, compared with four or five with the other preparations. The total incidence of negative phases in the 92 experiments was $21(23 \%)$. There were three patients whose F.E.V. fell to $40 \%$ below basal and two to $50 \%$, but the numbers are too small to implicate the preparations that were used.

As there was a very low incidence of rebound bronchoconstriction occurring soon after inhalation (less than $60 \mathrm{~min}$.), none of the preparations appeared likely to induce patients to make frequent use of the inhaler, and over-use from this cause is unlikely to occur.

Subjective side-effects attributable to cardiovascular stimulation were absent throughout.

\section{DISCUSSION}

Direct comparisons made between the five preparations as regards amplitude of peak activity and duration of effect are valid only in relation to the doses given. Altering the dose alters the peak response and must similarly alter the duration of effect. If the preparations had been 


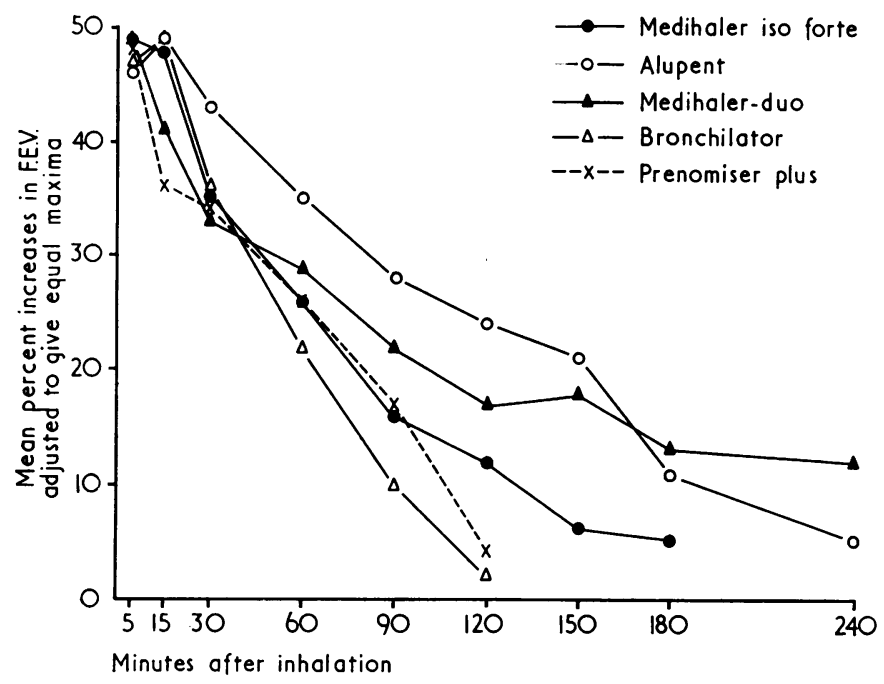

FIG. 4. Hypothetical mean percent increases in F.E.V. adjusted to give equal maxima. These curves are calculated on the assumption that the bronchodilator response to all components varies directly as the logarithm of the dose, and that the preparations have been given in doses that yield identical peak values.

administered in doses that yielded identical peak values, the resulting mean percentage increase curves would be the result of their respective decay characteristics alone, uninfluenced by the effect of differences in dosage. Since it has been shown that the response is related to the logarithm of the dose, it is possible to calculate, from the data shown in Fig. 3, hypothetical curves with identical peak values (Fig. 4). These curves show an advantage to Alupent up to $165 \mathrm{~min}$. and thereafter to Medihaler-duo. However, this computation needs experimental confirmation, and accordingly it is proposed to undertake a similar comparative trial in which the doses of the different preparations are standardized to yield identical or closely similar peak bronchodilator responses. Such an experiment should make possible a valid comparison of durations of effect and of side-effects.

The percentage increase over basal is most commonly used as a measure of bronchodilator effectiveness, and this tradition has been followed in this paper. There are, however, theoretical disadvantages to the use of the percentage increase which we propose to discuss elsewhere (see also Feinmann and Newell (1963)). One major drawback is that the distribution of this statistic tends to be positively skewed, so that the arithmetical mean is at the mercy of a few high readings. This is evidenced by the fact that the mean F.E.V. is considerably greater than the median F.E.V. for some preparations, especially around the time of maximum response. The best method of assessing duration of effect also requires further study.

There is evidence to suggest that bronchitics may respond better than asthmatics to atropine. Altounyan (1964) described a group of patients who were unresponsive to steroids and whom he regarded as primarily chronic bronchitics (Altounyan, 1968) ; their response to atropine was greater than that of a group of asthmatics. Crompton (1968) reported a rise in F.E.V. following subcutaneous injection of atropine, which was greater in bronchitics than in asthmatics. However, Kennedy and Thursby-Pelham (1964), who used Prenomiser Plus in the same dosage as ourselves and an almost identical method of assessment, obtained similar responses in asthmatics and bronchitics. These responses were well maintained for $3 \frac{1}{2}$ hours and did not fall away from the peak as occurred in our series. In a personal series of 13 bronchitics with severe emphysema the response to Prenomiser Plus was smaller than that of the asthmatics in this trial; the mean basal F.E.V. of the bronchitics was, however, lower than that of the asthmatics.

We thank the Bayer Products Company, Boeh ringer Ingelheim Limited, Fison Pharmaceuticals Limited, Riker Laboratories, and Vitalograph Limited for supplies of the preparations used, loan of equip ment and financial support, Mr. J. S. Bass, of Riker Laboratories, for clerical assistance, and the Board of Governors of King's College Hospital for a gran towards expenses. 


\section{REFERENCES}

Altounyan, R. E. C. (1964). Variation of drug action on airway obstruction in man. Thorax, 19, 406.

- (1968). Personal communication.

Astin, T. W., and Penman, R. W. B. (1967). Airway obstruction due to hypoxemia in patients with chronic lung disease. Amer. Rev. resp. Dis., 95, 567.

Capel, L. H., and Fletcher, E. C. (1964). Spirometric integrals after isoprenaline and atropine in asthma. Brit. J. Dis. Chest, 58, 174.

Chamberlain, D. A., Muir, D. C. F., and Kennedy, K. P. (1962). Atropine methonitrate and isoprenaline in bronchial asthma. Lancet, 2, 1019.

Cohen, A. A., and Hale, F. C. (1965). Comparative effects of isoproterenol aerosols on airway resistance in obstructive pulmonary diseases. Amer. J. med. Sci., 249, 309.

Crompton, G. K. (1968). A comparison of responses to bronchodilator drugs in chronic bronchitis and chronic asthma. Thorax, 23, 46.

Dautrebande, L., Lovejoy, F. W., and McCredie, R. M. (1962). Effects of atropine micro-aerosols on airway resistance in man. Arch. int. Pharmacodyn., 139, 198.

Edwards, G. (1964). Orciprenaline in treatment of airways obstruction in chronic bronchitis. Brit. med.J., 1, 1015.

El-Shaboury, A. H. (1964). Controlled study of a new inhalant in asthma and bronchitis. Ibid., 2, 1037.

Engelhardt, A., Hoef ke, W. and Wick, H. (1961). Zur Pharmakologie des Sympathomimeticums 1-(3,5-Dihydroxyphenyl)-1-hydroxy2-isopropylaminoäthan. Arzneimittel-Forsch., 11, 521.

Feinmann, L., and Newell, D. J. (1963). Isoprenaline in the treatment of chronic bronchitis. Brit. J. Dis. Chest, 57, 140.

Fischer, M., and Mielke, U. (1965). Vergleichende Untersuchungen über die Wirkung von Aludrin und Alupent als Sprüh-Aerosole. Med. Klin., 60, 1824.

Friedman, M. (1937). The use of ranks to avoid the assumption of normality implicit in the analysis of variance. J. Amer. Statist. Soc., 32, 675. .

Goldfarb, A. A., and Romanoff, A. (1962). Clinical evaluations of a new triple drug aerosol for asthma. Ann. Allergy, 20, 307.

Greenberg, M. J., and Pines, A. (1967). Press urized aerosols in asthma. (Correspondence.) Brit. med. J., 1, 563.

Herschfus, J. A., Bresnick, E., Levinson, L., and Segal, M.S. (1951). A new sympathomimetic amine ("Neosuprel") in the treatment of bronchial asthma. Ann. Allergy, 9, 769.

Hoff brand, B. I., Hoffbrand, M. I., Hill, I. D., and Heaf, P. J. D. (1966). Trial of bronchodilator drugs given by a metered aerosol with a comparison of two bedside methods of estimating airway resistance. Brit. med. J., 1, 1014.

Illig, H. (1965). Die Wirkung verschiedener Dosier-Aerosole auf die asthmatische Dyspnoe (Doppelblindversuch). Med. Klin., 60, 1452.
Jacobsen, M., and Prime, F. J. (1965). Comparisons of isoprenaline with a new bronchodilator combination (Bronchilator). Clin. Trials J., 2, 297.

Kallós, P., and Kallós-Deffner, L. (1963). Comparison of the protective effect of isoproterenol and isoproterenol-phenylephrine aerosols in asthmatics. Int. Arch. Allergy, 24, 17.

Kendall, M. G., and Stuart, A. (1966). The Advanced Theory of Statistics, Vol. 3, pp.1-56. Griffin, London.

Kennedy, M. C. S. (1965). "Bronchodilator" action of deptropine citrate with and without isoprenaline by inhalation. Brit. med. J., 2, 916 .

— and Thursby-Pelham, D. C. (1964). Some adrenergic drugs and atropine methonitrate given by inhalation for asthma: a comparative study. Ibid., 1, 1018.

Lands, A. M., Luduena, F. P., Grant, J. I., and Ananenko, E. (1950) The pharmacologic action of some analogs of 1-(3,4-dihydroxyphenyl)-2- amino -1- butanol (ethylnorepinephrine). J. Pharmacol exp. Ther., 99, 45.

Lockett, M. F. (1965). Dangerous effects of isoprenaline in myocardial failure. Lancet, $2,104$.

Mattila, M., and Muittari, A. (1966). The effect of bronchodilator aerosols on the peak expiratory flow rate in asthmatic patients. Acta med. scand., 180, 421.

Mushin, G. J. (1967). Time factor in the measurement of response to bronchodilators. Thorax, 22, 538.

Pickworth, K. H., and Westwood, J. (1965). Use of the Wright peak flow meter. A double-blind trial of two bronchodilator aerosols. Practitioner, 194, 260.

Prime, F. J. (1968). The relief of airways obstruction by deptropine citrate and isoprenaline. Brit. J. Dis. Chest, 62, 81 .

Scadding, J. G. (1963). The meaning of diagnostic terms in bronchopulmonary disease. Brit. med. J., 2, $1+25$.

Siegmund, O. H., Granger, H. R., and Lands, A. M. (1947). The bronchodilator action of compounds structurally related to epinephrine. J. Pharmacol. exp. Ther., 90, 254.

Sinclair, J. D. (1966). The response of asthmatics to bronchodilator aerosols. N.Z. med. J., 65, 524.

Speizer, F. E., Doll, R., Heaf, P., and Strang, L. B. (1968). Investigation into use of drugs preceding death from asthma. Brit. med.J., $1,339$.

Spitzbarth, H., and Albers, P. (1961). Beobachtungen über Veränderungen der physikalischen Kreislaufgrössen beim Menschen nach Verabreichung von 1-(3,5-Dihydroxyphenyl)-1-hydroxy-2-isopropylaminoäthan. Arzneimittel-Forsch., 11, 528.

Widdicombe, J. G., Kent, D. C., and Nadel, J. A. (1962). Mechanism of bronchoconstriction during inhalation of dust. J. appl. Physiol., 17,613 .

Woolcock, A. J., Tai, E. H., and Pain, M. C. F. (1964). Assessment of orciprenaline ("Alupent"), a long-acting bronchodilator. Med. J. Aust., 2, 89. 